Bangladesh Med Res Counc. Bull 2017-43.126-130

\title{
Hepatitis: Knowledge and Awareness among the Infected Population
}

\author{
Jobayer $\mathrm{M}^{1}$, Afroz $\mathrm{Z}^{1}$, Rahman $\mathrm{M}^{1}$, Akter $\mathrm{N}^{1}$, Shamsuzzaman $\mathrm{SM}^{1}$, Islam KMS ${ }^{2}$ \\ ${ }^{1}$ Department of Microbiology, Dhaka Medical College, Dhaka, Bangladesh \\ ${ }^{2}$ Department of Microbiology, BIRDEM General Hospital, Dhaka. Bangladesh \\ e-mail:mjobayerk52@yahoo.com
}

\begin{abstract}
Hepatitis viruses are serious global public health problem and rapidly spreading in the developing countries due to factors like illiteracy, lack of health education, poverty etc. The aim of this study was to assess the level of knowledge and awareness of hepatitis infected people toward the disease, its consequences, routes of transmission of virus and preventive measures including vaccination. This cross sectional study was carried out in the Department of Microbiology of Dhaka Medical Collage, Dhaka, Bangladesh from February to August 2013 among 2254 male jobseekers to Malaysia. History and other information were collected from HBsAg and anti-HCV positive persons by a predesigned questionnaire. Prevalence of hepatitis B virus infection in adult population was $2.35 \%$ and appears to be on decline and prevalence of hepatitis $\mathrm{C}$ virus infection was $0.13 \%$ that is still low in Bangladesh. No significant relationship was found between the demographic profile, religion, locality, occupation of the study population and hepatitis infection. In majority of the positive jobseekers, routes of transmission of viruses were not well established. Among infected population, about $90 \%$ had educational status below secondary level, who were from low income group, and $60 \%$ of them were unemployed. Three fourth of them did not have proper knowledge about the disease, only about $10 \%$ of them properly knew about the routes of transmission of hepatitis viruses, and $91 \%$ did not have adequate knowledge about the preventive measures including vaccination. Knowledge about hepatitis was poor among infected population and they were not much aware about the disease. So measures should be taken to create awareness among the population about hepatitis and the preventive measures to halt the transmission of such infections.
\end{abstract}

Keywords: Hepatitis, Knowledge, Transmission, Jobseekers

\section{Introduction}

Hepatitis $\mathrm{B}$ and $\mathrm{C}$ virus lead to chronic disease in hundreds of millions of people. ${ }^{1}$ Globally, two billion people have hepatitis B virus (HBV) infection and more than 170 million people are chronically infected with hepatitis $\mathrm{C}$ virus (HCV). ${ }^{2,3}$ Hepatitis by HBV is classified as 'disease of priority' due to the incessant increase in detection of new cases worldwide. ${ }^{4}$

Prevalence of hepatitis virus infection varies from country to country and within countries, having a close association with demographic, behavioural and environmental factors. ${ }^{5}$ Bangladesh, Indian subcontinent and parts of central Asia have 'Intermediate' prevalence
$(2-7 \%)$ of $\mathrm{HBV}$ infection. ${ }^{6}$ Prevalence of hepatitis B virus in Bangladesh is 4.9-6.2\% among general population and prevalence of $\mathrm{HCV}$ infection is $1-2.2 \%$. $^{7-11}$

People have been infected with hepatitis viruses by using improperly sterilised syringe, needle and even by tattooing or ear piercing. ${ }^{12}$ Number of HBV infection attributable to unsafe injection practice in low-income countries is 8-16 million every year. ${ }^{13}$ Knowledge and awareness about the disease and transmission of virus is vital in case of prevention of hepatitis. A significant proportion of population still is not very aware of the disease and its consequences. When the infected people have the correct knowledge they may take preventive measures not to transmit 
the virus to others or be aware to vaccinate the members of his family to eliminate the chance of transmission.

Knowledge is usually assessed to see how far community knowledge corresponds to biomedical concepts. ${ }^{14}$ Knowledge survey is representative of a specific population to collect information on what they know, believe and do in relation to a particular topic. ${ }^{15}$ This study was carried out to assess the depth of knowledge about the mode and routes of transmission of hepatitis viruses and level of awareness of the hepatitis infected people about different preventive measures including vaccination.

\section{Materials and Methods}

The cross sectional study was conducted in the Department of Microbiology, Dhaka Medical College, Dhaka, Bangladesh from February to August 2013, among adult (18-45 years) male jobseekers from Bangladesh to Malaysia under the Government to Government $\left(\mathrm{G}_{2} \mathrm{G}\right)$ project, who attended for health checkup in the department. A total of 2254 male jobseekers were enrolled in this study. Written consents were obtained from the study population. Participants deserved the rights to participate or withdraw himself at any point of the study. Anonymity of the participants and confidentially of information was maintained strictly.

Study procedure: Health checkup was done, several demographic data were collected and they were screened for different diseases including hepatitis $\mathrm{B}$ and $\mathrm{C}$ virus. $\mathrm{HBs} \mathrm{Ag}$ and anti-HCV were detected by ELISA method using commercial reagent (Mediment Diagnostic \& Company, Ireland). Further information was collected from the jobseekers who were found positive for hepatitis viruses.

Data collection procedure: Data were collected from the hepatitis infected population by a predesigned questionnaire.

Questionnaire design:A close ended questionnaire was used that included information regarding the patient's identity, background history, any possible route of transmission of viruses and patients knowledge about the disease, mode of transmission, preventive measures and vaccination. The questionnaire was pretested before data collection.

Knowledge and awareness was measured by asking several questions about disease, route and preventive measures. The questions regarding symptoms of hepatitis, complication of the disease, causative agents; routes- oral, parenteral, vertical; materials with which viruses may transmit, activities that will and will not transmit the viruses and availability, schedule, sites of hepatitis vaccine were asked.

Data management: Collected data were classified according to characteristics and 'Microsoft Excel' software was used for analysis.

\section{Results}

Out of the 2254 enrolled population, 53(2.35\%) waspositive for $\mathrm{HBsAg}$ and anti-HCV was detected in $3(0.13 \%)$ population, none was coinfected with hepatitis $\mathrm{B}$ and $\mathrm{C}$ virus (table I).

Table I: Distribution of hepatitis (B and C) infection among jobseekers $(\mathrm{n}=2254)$

\begin{tabular}{lccc}
\hline \multicolumn{1}{c}{ Infection } & $\begin{array}{c}\text { Total } \\
\text { population }\end{array}$ & $\begin{array}{c}\text { Positive } \\
\text { cases }\end{array}$ & Percentage \\
\hline $\begin{array}{l}\text { Hepatitis B virus } \\
\text { infection }\end{array}$ & 2254 & 53 & 2.35 \\
$\begin{array}{l}\text { Hepatitis C virus } \\
\text { infection }\end{array}$ & 2254 & 3 & 0.13 \\
\hline
\end{tabular}

Among hepatitis infected individuals, $89.3 \%$ had educational status below SSC level, $60.7 \%$ was unemployed and $87.5 \%$ people were from low income group (table II).

Table II: Demographic profile of hepatitis virus infected individuals $(\mathrm{n}=56)$

\begin{tabular}{llc}
\hline \multicolumn{2}{l}{ Demographic profile } & Hepatitis positive n (\%) \\
\hline Educational & Below SSC* & $50(89.3)$ \\
status & & $6(10.7)$ \\
& Above SSC* & $34(60.7)$ \\
Employment & Unemployed & $22(39.3)$ \\
& Employed & $49(87.5)$ \\
Economical & Lower income group & $7(12.5)$ \\
condition & & \\
& Middle income group &
\end{tabular}


Seventy three percent hepatitis infected person had inadequate knowledge about hepatitis disease. Only $10.71 \%$ of the study population had proper knowledge about mode of transmission of hepatitis viruses. Majority $(91.07 \%)$ people had no knowledge or inadequate knowledge about preventive measures against hepatitis and $94.65 \%$ of them did not know about the correct schedule of hepatitis vaccination (table III).

Table III: Level of knowledge of the hepatitis positive population

\begin{tabular}{lccc}
\hline $\begin{array}{l}\text { Knowledge } \\
\text { about }\end{array}$ & $\begin{array}{c}\text { No } \\
\text { knowledge } \\
\mathbf{n}(\%)\end{array}$ & $\begin{array}{c}\text { Incomplete/Ina } \\
\text { dequate } \\
\text { knowledge } \\
\mathbf{n}(\%)\end{array}$ & $\begin{array}{c}\text { Proper } \\
\text { knowledge } \\
\mathbf{n}(\%)\end{array}$ \\
\hline $\begin{array}{l}\text { Hepatitis } \\
\text { disease }\end{array}$ & $2(3.57)$ & $41(73.21)$ & $13(23.21)$ \\
$\begin{array}{l}\text { Transmission } \\
\text { of virus }\end{array}$ & $19(33.93)$ & $31(55.36)$ & $6(10.71)$ \\
$\begin{array}{l}\text { Measures of } \\
\text { precaution }\end{array}$ & $22(39.29)$ & $29(51.78)$ & $5(8.93)$ \\
\begin{tabular}{l} 
Vaccination \\
\hline
\end{tabular} & $22(39.29)$ & $31(55.36)$ & $3(5.35)$ \\
\hline
\end{tabular}

\section{Discussion}

Among the jobseekers, $2.35 \%$ individuals were infected with hepatitis B virus and $0.13 \%$ was found positive for hepatitis $\mathrm{C}$ virus. Hepatitis infections are rapidly spreading in developing countries like Bangladesh due to illiteracy, lack of health education, poverty, and lack of hepatitis B vaccination. ${ }^{10}$

More than three fourth of the infected population in this study did not have a proper idea about the hepatitis disease, like the causes and the consequences. In a similar study in Bangladesh, it was reported that majority population had lack of knowledge regarding the sequel of hepatitis B virus infection. ${ }^{16}$ Very few of the hepatitis positive people had proper knowledge about the different routes or modes of transmission of the viruses. Some of them only knew about the major routes like sexual transmission, through blood or vertical transmission. About $90 \%$ of them did not at all know about the so called minor routes of transmission that includes sharing blades during shave or hair cut in barber shop or nose and ear piercing. In low income countries about one third of HBV infection is transmitted through unsafe injection practices or by sharing needles or blades. ${ }^{6,13,17}$

Majority of the positive people had a very little knowledge about the different measures that should be taken to prevent hepatitis. Vaccination against HBV has been introduced in EPI in Bangladesh in 2005. ${ }^{18}$ Among the study population only $3.57 \%$ gave history of taking hepatitis $\mathrm{B}$ vaccine though full course was not completed and maximum of them had very little idea about the schedule or availability of the vaccine. This finding was consistent with a study which reported that three fourth of general Bangladeshi population were not familiar with HBV vaccine. ${ }^{16}$ Similar result was reported by Lim and Rashwan who mentioned a low vaccination rate among participants from rural areas and that was probably due to low level of knowledge about the disease and theunavailability of vaccines. ${ }^{19}$ In agreement to the present study Haqet al in Pakistan reported that a small percentage of respondents actually knew about HBV vaccination. ${ }^{20}$ But in Egypt, it wasto be found that participants had adequate knowledge towards transmission and vaccination of hepatitis. ${ }^{21}$ Possible reasons that may have attributed to this difference of response are demographic variation, level of educationof study population, as well as study location.

Educational status may not be considered as a risk factor, but infection was more prevalent in people having educational status below secondary school level in this study. Data of BDHS also showed that knowledge about transmission of diseases as well as rate of vaccination was less among illiterate and low incomegroup. $^{22}$ Illiteracy is one of the main factors regarding lack of knowledge about hepatitis infection and other related 
information. ${ }^{20,21}$ There is no formal school based health education in Bangladesh which may be an important reason for low level of knowledge. Awareness programme against hepatitis should be included in primary and secondary education. Mass media like television, radio, newspaper should be used extensively to create awareness about hepatitis and preventing measures. Healthcare providers should counsel with the people during home or hospital management.

Findings of this study may highlight the need for prevention and control of hepatitis infection in Bangladesh by implementing the universal vaccination and creating public awareness to promote the use of disposable needles for ear or nose piercing. Although this study included jobseekers but as they were from different districts of the country, results obtained from this study not only imply to jobseekers but also it may represent the general population of Bangladesh in terms of knowledge and awareness. This study may provide a useful basis for the future studies in this area, including assessment of related risk factors.

\section{Conclusion}

It may be concluded that general knowledge about hepatitis was poor and level of awareness among the study population towards the disease and preventive measures was not optimum. So, strengthening awareness programme, aimed to prevent and control HIV/AIDS are thus recommended.

\section{Acknowledgement}

The work was supported financially by the Department of Microbiology, Dhaka Medical College, Dhaka, Bangladesh. The authors thankfully acknowledge the Bureau of Manpower, Employment and Training (BMET), Bangladesh for providing the data collection facilities.

Conflict of interest: Authors did not have any conflicts of interest.

\section{Reference}

1. WHO Hepatitis. 2011[cited 2015 July 30]. Available from: http://www.who.int/ topics/ hepatitis/en.

2. Hepatitis B: 2008 [cited 2015 November 30]. Available from:http://www.who.int/mediacentre/factsheets/fs 204/en.

3. Hepatitis C. [cited 2016 January 3]. Available from:http://who.int/mediacentre/factsheets/fs164/en

4. Lok ASF,McMahon BJ. Chronic hepatitis B: update 2009. Hepatol. 2009; 50: 661-62.

5. Chowdhury SGM, Ahmed Q, Islam MN. HbsAg in unscreened operated patients. BMRC Bull.1991; 17: 11-16.

6. Sarin SK, Kumar M. Epidemiology, screening and natural history of chronic Hepatitis B infection. In: Shetty K and Wu GY. Eds. Chronic Viral Hepatitis. Diagnosis and Therapeutics. 1st ed. New York: Humana Press, Springer Science Business Media. 2001.p 186-87.

7. Gibney L, Saquib N, Metzger J, Choudhury P, Siddiqui MA, Hassan MS. Human immunodeficiency virus, hepatitis $\mathrm{B}, \mathrm{C}$ and $\mathrm{D}$ in Bangladesh's trucking industry: prevalence and risk factors. Int J Epidemiol. 2001; 30: 878-84.

8. Afroz H, Hossain MM, Fakruddin M, Khan MAR, Khan ZUM, Datta S. A retrospective study on seroprevalence of hepatitis B virus surface antigen (HBsAg) among healthy individuals attending a tertiary care clinic in Dhaka, Bangladesh. Int J Biomed Res. 2013; 4: 245-50.

9. Rudra S, Chakrabarty P, Poddar B. Prevalence of hepatitis $\mathrm{B}$ and hepatitis $\mathrm{C}$ virus infection in human of Mymensingh, Bangladesh. Mymensingh Med J. 2011; 20: 183-86.

10. Ashraf H, Alam NH, Rothermundt C, Brooks A, Bardhan P, Hossain L,et al. Prevalence and risk factors of hepatitis $\mathrm{B}$ and $\mathrm{C}$ virus infections in an impoverished urban community in Dhaka, Bangladesh. BMC Infect Dis. 2010; 10: 208-09.

11. Mahtab MA, Rahman S, Karim F, Foster G, Solaiman S. Epidemiology of Hepatitis C Virus in Bangladeshi General Population. BSMMU J. 2009; 2: 14-17.

12. Butel JS. Hepatitis viruses. In: Brooks GF, Carroll KC, Butel JS, Morse SA, Mietzner TA. Eds. Jawetz, Melnick \&Adelberg's Medical Microbiology. 25th ed. New York: McGraw-Hill; 2007. p 320-29.

13. Kane A, Lloyd J,Zaffran M, Simonsen L, Kane M. Transmission of hepatitis B, hepatitis $\mathrm{C}$ and human immunodeficiency viruses through unsafe injections in the developing world: model-based regional estimates. WHO Bull. 1999; 77: 801-7. 
14. Kabir A, Tabatabaei SV, Khaleghi S, Agah S, KashaniAHF, MoghimiMet al . Knowledge, attitudes and practice of Iranian medical specialists regarding hepatitis B and C. Hepatol Mon. 2010; 10: $176-82$.

15. Razi A, Rehman RU, Naz S, Ghafoor F, Khan MAU. Knowledge, attitude and practices of university students regarding hepatitis $\mathrm{B}$ and $\mathrm{C}$. ARPN J Agricultural Biological Sci.2010; 5: 38-43.

16. SweetyKN, Mimi SA. Awareness of hepatitis B vaccination in rural area: a survey. J Curr Adv Med Res. 2014; 1: 3-7.

17. Memon MI and Memon MA. Hepatitis C: an epidemiological review. J Viral Hepatol. 2002;9: 84-100.

18. Hepatitis B vaccine. [cited 2015 October 11]. Available from:http:/www.who.int/ immunizationmonitoring/data/data_subject/en/index.html year of introduction of selected vaccine. Database.
19. Lim HC, Rashwan H: Awareness of hepatitis A and hepatitis B among residents in Kuala Lumpur and Selangor. Malaysian J Pharma. 2003; 1: 76-85.

20. Haq NU, Hassali MA, Shafie AA, Saleem F, Farooqui M, Aljadhey H. A cross sectional assessment of knowledge, attitude and practice towards Hepatitis B among healthy population of Quetta, Pakistan. BMC Public Health. 2012; 12: 692.

21. ShalabyS,KabbashIA,ElSaleetG,Mansour N, Omar A, El-Nawawy A. Hepatitis B and C viral infection: prevalence, knowledge, attitude and practice among barbers and clients in Gharbia Governorate, Egypt. East Mediterr Health J. 2010; 16: 10-17.

22. BDHS 2007. Bangladesh Demographic and Health Survey. National Institute of Population Research and Training (NIPORT). Ministry of Health and Family Welfare, Bangladesh. 2009. 